\title{
Leadership SQ - The Vedic way: Enhancing the spiritual quotient of future managers
}

\author{
Tarun Pasricha \\ Goa Institute of Management, India
}

\begin{abstract}
A high Spiritual Quotient (SQ) is increasingly being regarded as an essential pre-requisite for effective leadership. However, little research is available on the methodology one should employ to develop and increase the spiritual quotient of future leaders. This article concerns itself precisely with this question and describes a course that was designed in a business school to impart a spiritual dimension to future leaders in the corporate sector. The course relied primarily on ancient Indian scripture - Vedanta or the essence of the Vedas - along with comparative studies of Western 'new age' spiritual thought to enhance the SQ of young MBA students. The article describes the course structure, pedagogy and evaluation scheme employed and the feedback from the students who participated.
\end{abstract}

Keywords: Spiritual quotient, SQ, Leadership, Management, Course design, Business school curriculum, Vedanta, Vedas, Upanishads

\section{INTRODUCTION}

During my three decades as a practitioner in the field of sales, marketing and business development, I had always wondered at how otherwise smart and charismatic business leaders seemed to be singularly lacking in the emotional and spiritual departments. Nothing exemplified this more than the Wall Street collapse a few years ago where the sheer greed of a few wreaked havoc on millions of ordinary citizens.

I had also been interested in traditional Indian philosophy, particularly the spiritual treasure which is the body of wisdom called the Vedas, and it struck me that many aspects of this knowledge could be utilised to enhance the 'spiritual quotient' or 'SQ' of leaders in the making - namely, students in a business school (B-school).

From this arose the idea of an experimental course entitled "Leadership SQ - The Vedic Way" which I first floated as an elective in January 2012 and will be offering for a third time in January 2014.

\section{LITERATURE REVIEW}

This article is more in the nature of a description of an innovative course design rather than a traditional research paper, so in this section I will merely point out a few references which were instrumental in:

- identifying behaviour/traits which would be natural outcomes of an enhanced spiritual quotient and would contribute to effective leadership

- validating the assumption that exposure to the concepts embodied in Indian traditional thought would enhance spiritual quotient.

My primary source of inspiration was a 2005 article, "Spiritually intelligent leadership", by Danah Zohar, physicist, philosopher and management thought leader. The following excerpts from this article are relevant:

Great leadership depends primarily on vision - not just any type of vision, but one that people can appreciate intellectually, emotionally, and spiritually. One reason that visionary leadership is in short supply today is the value our society places on one particular kind of capital - material capital. Too often the worth or value of an enterprise is judged by how much money it earns at the end of the day, or how much worldly power it gives us over others. This obsession with material gain has led to short-term thinking and the narrow pursuit of self-interest. It is true that any kind of enterprise we want to engage in requires some kind of financial wealth if it is to

Correspondence concerning this article should be addressed to Tarun Pasricha, Goa Institute of Management, Sankhali, Goa 403505, India. email: prof.tarunp@gmail.com 
succeed in the short term. But for leadership to inspire long-term, sustainable enterprises, it needs to pursue two other forms of capital as well: social and spiritual.

Leaders build all three forms of capital - material, social, and spiritual - by using their own intelligence. Intelligence itself is of three types: of the mind (IQ or Intelligence Quotient), of the heart (EQ or Emotional Quotient) and of the spirit (SQ or Spiritual Quotient).

IQ refers to rational, logical, rule-bound, problem-solving, goal-oriented intelligence. EQ is manifested in trust, empathy and in the ability to respond appropriately to the emotions of others. SQ, our spiritual intelligence quotient, underpins IQ and EQ. Spiritual intelligence is an ability to access higher meanings, values, abiding purposes, and unconscious aspects of the self and to embed these meanings, values, and purposes in living a richer and more creative life.

Signs of high SQ include an ability to think out of the box, humility, and an access to energies that come from something beyond the ego, beyond just me and my day-to-day concerns. SQ is the ultimate intelligence of the visionary leader. It was the intelligence that guided men and women like Churchill, Gandhi, Nelson Mandela, Martin Luther King Jr., and Mother Teresa. The secret of their leadership was their ability to inspire people, to give them a sense of something worth struggling for.

Danah Zohar then offers a framework for fostering spiritually intelligent leadership by nurturing the following traits:

- Self-awareness: knowing what I believe in and value, and what deeply motivates me

- Spontaneity: living in and being responsive to the moment

- Being vision- and value-led: acting from principles and deep beliefs, and living accordingly

- Holism: seeing larger patterns, relationships, and connections; having a sense of belonging

- Compassion: having the quality of "feeling-with" and deep empathy

- Celebration of diversity: valuing other people for their differences, not despite them

- Field independence: standing against the crowd and having one's convictions

- Humility: having the sense of being a player in a larger drama, of one's true place in the world

- Urge to ask fundamental 'Why?' questions: need to understand things in depth, not just superficially

- Ability to reframe: to stand back from a situation or problem and see the bigger picture

- Positive use of adversity: Learning and growing from mistakes, setbacks, and suffering

- Sense of vocation: feeling called upon to serve, to give something back.

Thus there are positive behavioural outcomes for leaders who choose to enhance their spiritual quotient.

Obviously, the next question is: how to enhance this spiritual quotient? This course is based on the premise that ancient Indian wisdom as embodied in the Vedas can contribute directly to the nurturing of many of the above traits, resulting in leadership with a high SQ. It is the intention of the course to expose students to carefully selected learning from Vedanta - the essence of the Vedas - which have been a source of knowledge and spiritual transformation for millions across the world, since time immemorial.

While it is not the purpose of this article to describe the vast body of literature which encompasses traditional Indian philosophy, since this information is readily available in the public domain, a brief description is in order. Indian thought owes its foundation to the four great spiritual treatises - the Vedas - which Indians believe were 'revealed' to mankind and are not considered to be the authorship of mere mortals. The four Vedas are: Rig Veda, Yajur Veda, Sama Veda and Atharva Veda. Each of these Vedas is further subdivided into four sections, three of which cover 'ritualistic' aspects, and a fourth, 'spiritual' portion. This last portion is referred to as Vedanta (literally the 'end of the Vedas') and comprises philosophical treatises called Upanishads. The well-known Upanishads are 108 in number, of which ten are considered 'principal' or 'prominent'. In addition, great Indian sages and philosophers have written commentaries on the various Upanishads and these commentaries are a source of learning in their own right.

On how the study of the Vedas, particularly the Upanishads, can contribute to enhancing one's spiritual 
quotient, a few (edited) excerpts from the e-book, Lessons on the Upanishads, by Swami Krishnananda are relevant:

What do the Upanishads tell us? They tell us the mode, the modus operandi of directly contacting the Spirit of the universe through the Spirit that is inside us - not by word of mouth, not by speaking any word, not by performance of any ritual. There is no need of any temple, church or scripture; we want nothing except our own Self. When we reach the Spirit of the universe, nothing will come with us. We will go there alone. We are the most important thing in this world, and not what we possess. The possessions will leave us, but we will carry ourselves. The Upanishads are the doctrine of the lifting of your own self to the Self of the universe, the Spirit which you are. It is not merely the Spirit inside you - you yourself are the Spirit.

The Upanishads are not prayers offered to some god which we can just chant every day as a routine of practice. They do not tell us how to perform rituals or gestures of worship as we do in temples or altars of adoration. They tell us something quite different from all these things. What is this differentia which marks the Upanishads? They deal with our Self.

The Upanishads are not telling us about any God. They are speaking about God, but not about the God that we usually think in our mind according to our upbringing, culture, language or tradition. They refer to God alone and nothing else, whereas the other religious forms of the concept of God have other things in addition to and simultaneous with God's existence, such as: something must be done, something must not be done. These 'dos' and 'don'ts' fill the texture of every religion in the world. Something has to be done and something should not be done. The question of this dichotomy does not arise in the Upanishads.

The concept of God, or the Ultimate Reality, often referred to as the Parabrahma or Paramatma that one encounters in the Upanishads is markedly different from the transcendent conception of God. The traditional concept of God is some supreme power who is far from us - up in the heavens, for instance (the concept of distance and space). Also, there is the belief that one will attain God after some lapse of time ('one day'), perhaps only after some considerable effort is expended (the concept of time and causality). The distinguishing feature of Indian spiritual thought is the belief that the Ultimate Reality is beyond the human concepts of space, time and causality and is both transcendent and immanent.

The essence of the Upanishads is found in one of their Great Statements: Tat Tvam Asi: "That Thou Art". Essentially the individual self and the universal Self are one; you are one with everyone else, and even inert nature and consciousness are part of the one, indivisible reality - Ekam Eva Advitiya, literally "The Only One, Without a Second." This realisation, when accepted not superficially, but by the core of one's being, has the power to transform one's behaviour and interaction with the external world. It is a deep understanding which enhances one's spiritual quotient and provides moksha or liberation from our everyday mundane existence.

\section{METHODOLOGY}

The challenges in designing a course to enhance leadership SQ in a B-school are many:

- There is a common belief that interest in matters spiritual is inversely correlated to one's age - hence getting young MBA students to opt for such a course is likely to be difficult

- The subject matter itself, 'spirituality', might be considered inappropriate for a business school

- Designing the pedagogy and course material to teach 'spirituality' in a classroom setting poses difficult challenges

- A degree of academic rigour is required from every course in a B-school, which might be difficult to incorporate in a course of such a nature.

\section{Choosing the study material}

The first step in designing a course of this nature is choosing the specific material from the Vedas which will be studied. After much deliberation, two treatises were chosen:

- Tattvabodha - a famous summary on Vedantic teachings by Shankaracharya.

- Ishavasya Upanishad - one of the ten principal Upanishads. 
Shankaracharya is the most famous persona in the lineage of great Indian sages and commentators. He was born in Kerala, India in 798 A.D., and as a precocious child, he mastered the four Vedas by the time he was eight years old. He wrote commentaries on virtually all the important Vedantic texts and his interpretations of the original material carry great weight among scholars. He died at the young age of 32 but by then he had established the four great learning and spiritual centres in India and his legacy lives on to this day.

In the ancient scholarly tradition of India, the three basic texts a student of Vedanta studies from a Guru are:

- The Upanishads - the Shruti or revealed knowledge

- The Brahma Sutra - the Yukti or logical texts

- The Bhagavad Gita - the Smriti or remembered tradition.

Together they are known as Prasthan Trayi or literally 'the three points of departure'. If the new initiates were to start a study of these three texts directly, they would find it very tough to comprehend them and that is why the fresh students are first exposed to the 'vocabulary' of the texts through Prakarna Granth, literally 'introductory texts'.

Tattvabodha, attributed to Shankaracharya, is one of the most famous introductory texts to Vedanta and is an essential pre-requisite to the study of the Upanishads. Tattvabodha literally means 'knowledge of the self'. While the primary role of the Tattvabodha is to expose the initiates to the various concepts and technical terms embodied in the various Upanishads, its value does not end there. Shankaracharya's brilliant commentary on the concepts results in the text becoming more a summary of the principal Upanishads rather than a mere introductory text, according it scriptural status in its own right. An overview of the concepts covered by the Tattvabodha is detailed in Appendix 1.

The Ishavasya Upanishad is one of the ten principal Upanishads. This Upanishad constitutes the final chapter of the Yajur Veda and is one of the shortest texts in Vedanta, consisting of a mere 18 verses. Indian tradition also specifies the order in which the ten principal Upanishads should be studied, and the Ishavasya Upanishad is the first in this sequence.

Its name derives from Isha ('by the Lord') and its significance lies in its non-dual perspective of the universe and its unparalleled description of the nature of the Supreme Being. Some scholars have also advanced the proposition that the 18 shlokas or 'verses' of the Ishavasya Upanishad are the source material for the 18 chapters of the Bhagavad Gita - the most well-known of Indian spiritual texts. Mahatma Gandhi thought so highly of this text that he remarked, "If all the Upanishads and all the other scriptures happened all of a sudden to be reduced to ashes, and if only the first verse in the Ishavasya Upanishad were left in the memory of the Hindus, Hinduism would live for ever".

The course also incorporated comparative study of Indian spiritual thought with Western 'new age' spirituality. The purpose was to find similarities and contradictions but ultimately to realise that most spiritual concepts were universal in nature. The two texts chosen for comparison with Vedanta were Conversations with God (Book 1) by Neale Donald Walsch and The Power of Now by Eckhart Tolle. The latter texts were chosen not only for their 'bestseller' status but because both the authors had spent some time in the East and their writings incorporated many learnings from Indian spiritual tradition.

The International Institute of Management (IIM), based in Las Vegas, USA, has as its Mission to "Leverage global knowledge networks to provide government and business leaders with the latest and most advanced management thinking". IIM's Management Society recognises and honours the 'World's Most Respected Spiritual Books'. Their researchers' criteria for accepting nominations include the importance of the work, media coverage, recognition within the consulting, academia and international management communities. Conversations with God (Book 1) by Neale Donald Walsch features prominently in this list. Also, Amazon.com lists 1,718 customer reviews for this book (with an average rating of 3.8 out of 5 stars) and the majority of the reviewers have written about the transformational effect this book has had on them, spiritually.

Similarly, The Power of Now by Eckhart Tolle has 1,825 reviews on the Amazon site with an average rating of 4.3 out of 5 stars. Amazon's own review states: "Much more than simple principles and platitudes, the book takes readers on an inspiring spiritual journey to find their true and deepest self and reach the ultimate in personal growth and spirituality: the discovery of truth and light." And: "the Power of Now reads like the highly acclaimed $A$ Course in Miracles - a spiritual guidebook that has the potential to inspire just as many study groups and change just as many lives for the better". 


\section{Pedagogy}

Indian tradition requires that spiritual texts such as the Upanishads should be 'heard' rather than 'read'. Sitting down near (one's Guru to listen to the teaching) is in fact a literal translation of the word Upanishad.

Accordingly the course was designed in a manner where approximately half of each 90-minute classroom session required the students to listen to/watch an audio/video discourse on the Tattvabodha and Ishavasya Upanishad delivered by one of the foremost contemporary Vedanta teachers in the country - Swami Anubhavananda. The discourses had a degree of academic rigour in that they were a verse-by-verse translation and commentary of the original Sanskrit text and students were required to pay attention to the flow of the talk by referring to the specially prepared course material provided to them.

The course material provided to the students had the original Sanskrit text with the meanings of each word and a literal translation provided in English. The audio/video recording provided the interpretation of the literal translation which would otherwise have been difficult to assimilate.

The role of the faculty was to summarise the discourses, provide greater clarity on the issues raised, introduce additional Vedantic concepts where deemed necessary to enhance learning, and invite class discussion on the subject material. A sample of the course material is given in Appendix 2.

\section{Course structure and evaluation scheme}

The course structure consists of classroom sessions devoted to Tattvabodha, Ishavasya Upanishad and comparative studies of spiritual thought.

Each of the sessions on Tattvabodha and Ishavasya Upanishad requires students to submit a one-page summary of the learning from the session and pick at least one principle which they intended to apply in either their personal life or career.

Group presentations are incorporated in the course to encourage comparative study between the Eastern and Western texts described earlier.

At the end of the course there is an end-of-term written exam which requires students to pick some of the 12 spiritual traits from Danah Zohar's framework (referred to earlier) and give examples of how those traits would foster successful corporate leadership. Examples could be based on actual past experience, or future scenarios could be visualised where those traits would be useful.

An outline of the course is attached in Appendix 3.

The evaluation schema adopted is designed to test whether students have:

- internalised the teachings and are both able and willing to apply it in their personal life - the tool for this is the individual submission referred to earlier

- recognised the universality of the teaching which is not limited to any particular region or ethnicity this emerges from the comparative presentations of the Eastern and Western texts

- realised how the enhancement of one's SQ can result in more effective business leadership - as evidenced from the end-of-term exam where they are required to envision corporate scenarios where spiritual principles can be usefully applied.

From the performance of students in each of the above evaluation components, an assessment of their progress clearly emerges. The higher the quality of the submissions, the higher the achievement in the course and at the end of the course, the scores tend to fall into a normalised relative grading system, with data points across the spectrum from $\mathrm{A}$ + to $\mathrm{C}$-.

\section{RESULTS}

While no specific research has as yet been undertaken to gauge the increase in SQ of students who have attended the course during its last two iterations, the quality of their final exam submissions indicates a desire to apply spiritual principles as future business leaders. Also available are standard course feedbacks for the last two years which are summarised in Table 1 below. 
Table 1: Student feedback

\begin{tabular}{|l|r|r|}
\hline & $\mathbf{2 0 1 2}$ & $\mathbf{2 0 1 3}$ \\
\hline No. of students & $\mathbf{7 7}$ & $\mathbf{6 2}$ \\
\hline $\begin{array}{l}\text { Relevance of reading material used in the course: } \\
\text { 5:Highly relevant, 3:Relevant, 1:Not relevant }\end{array}$ & 4.40 & 4.62 \\
\hline $\begin{array}{l}\text { Quality of reading material? } \\
\text { 5:Very good, 3: Reasonable, 1:Very poor }\end{array}$ & 4.34 & 4.56 \\
\hline $\begin{array}{l}\text { Pedagogy used was: } \\
\text { 5:Very effective, 3:Effective, 1:Not effective }\end{array}$ & 4.15 & 4.26 \\
\hline $\begin{array}{l}\text { Pedagogy used was: } \\
\text { 5:Very appropriate, 3:Appropriate, 1:Not appropriate }\end{array}$ & 4.20 & 4.19 \\
\hline $\begin{array}{l}\text { Components of evaluation appropriate as a test of } \\
\text { learning in this course? }\end{array}$ & 4.36 & 4.59 \\
5:Most appropriate, 3: Appropriate, 1:Not appropriate & 4.43 & 4.58 \\
\hline $\begin{array}{l}\text { Communication? } \\
\text { 5:Excellent, 4:Good, 3:Alright, 2:Poor, 1:Very poor }\end{array}$ & 4.43 \\
\hline $\begin{array}{l}\text { Ability to enthuse participants: } \\
\text { 5:High, 3:Moderate, 1:Low }\end{array}$ & 4.21 & 4.19 \\
\hline $\begin{array}{l}\text { Response to questions, doubts raised by participants: } \\
\text { 5:Excellent, 4:Good, 3:Alright, 2:Poor, 1:Very poor }\end{array}$ & 4.30 & 4.50 \\
\hline $\begin{array}{l}\text { Timeliness and quality of feedback: } \\
\text { 5:Excellent, 4:Good, 3:Alright, 2:Poor, 1:Very poor }\end{array}$ & 4.43 & 4.44 \\
\hline $\begin{array}{l}\text { Preparedness? } \\
\text { 5:Excellent, 4:Good, 3:Alright, 2:Poor, 1:Very poor }\end{array}$ & 4.40 & 4.52 \\
\hline $\begin{array}{l}\text { Overall effectiveness? } \\
\text { 5:Excellent, 4:Good, 3:Alright, 2:Poor, 1:Very poor }\end{array}$ & 4.38 & 4.42 \\
\hline $\begin{array}{l}\text { Extent of learning in this course: } \\
\text { 5:Excellent, 4:Very high, 3:High, 2:Moderate, 1:Low }\end{array}$ & 4.28 \\
\hline $\begin{array}{l}\text { How would you rate this course on a scale of 1 to 5? } \\
\text { 1:Lowest, 5: Highest }\end{array}$ & 4.38 & 4.33 \\
\hline
\end{tabular}

Particularly heartening is the feedback on the relevance of the course material and the appropriateness of the pedagogy employed.

\section{CONCLUSION}

A question worth asking is whether the Purpose, Method and Evaluation criteria adopted by the course make it appropriate for inclusion in the curriculum of a business school?

There is an increasing body of evidence which supports the inculcation of spiritual values at business schools. For example, it has been argued (Gherman \& Marquina, 2012):

We propose therefore the study of a course entitled Spiritual Leadership, as a practical and innovative way for a Catholic University to engage the Catholic heritage and the disciplines of business and liberal education. There is a necessity to create future Spiritual Leaders that can lead their organizations and followers based on the principles of human dignity, subsidiarity, solidarity, etc., and above all, who are able to integrate the employee's personal spiritual needs and values into the everyday work environment through thoughts and actions that reflect and nourish those needs and values. The Spiritual Leader is the one that addresses not only the physical and mental needs of his workers, but also the spiritual ones. We argue and support the idea according to which spirituality can lead towards the creation of better organizations, benefiting the entire society. We believe in the existence of a better world, but we think that this will happen not only by being a servant leader, but when we will really understand and live based on our values.

So, a course on Spiritual Leadership is appropriate for a business school to the extent that its purpose is to enhance the spiritual quotient of future corporate leaders. How an enhanced SQ contributes to effective 
business leadership has already been expounded earlier (Zohar, 2005). Also, the course fits in well with other courses offered in a typical B-school, such as those on Corporate Ethics and Corporate Social Responsibility.

Turning next to the question of Method, the attempt has been to rely on both Eastern and Western spiritual texts so that the universality of the wisdom is brought home to the students. Depending on the geographical and cultural context, the choice of the primary texts used can be changed and customised. For example, in India, reliance on Eastern texts is more appropriate.

Finally, on the issue of Evaluation criteria, the mix of individual exercises, group presentations and an end-ofterm exam meets the requirements of academic rigour specified by business schools. Also the evaluation components focussed on the envisioning of business scenarios where leadership with a high SQ would be effective, and this certainly met the test of appropriateness for a B-school.

It would seem that the course objectives have been largely met, as reflected not only in the formal student feedback but also in the quality of the daily submissions, comparative presentations and final exam papers, which constituted the various assessment components. There is therefore hope that this course will be a small first step in enhancing the spiritual growth of future business leaders.

\section{ACKNOWLEDGEMENTS}

This course could not have been designed without the support, encouragement and guidance of my spiritual teacher, Swami Anubhavananda, whose audio and video recordings form the backbone for imparting knowledge to the students. For those who wish to know more about this towering personality, visit the following websites:

\section{www.behappyinc.org/AboutAnubhav.aspx}

http://www.gurusfeet.com/guru/swami-anubhavananda\#tabset-3

I also wish to acknowledge the support of my employer, Goa Institute of Management, India, for encouraging the development of a course in spirituality - a somewhat unusual decision for a business school!

\section{REFERENCES}

Gherman, Tatiana \& Marquina, Percy (2012). Spirituality and leadership. CENTRUM Católica's Working Paper Series No. 2012-09-0018 / September 2012.

Swami Krishnananda, Lessons on the Upanishads. E-book: http://www.swamikrishnananda.org/upanishad.html

Swami Tejomayananda (2000). Tattva Bodhah of Sri Adi Sankaracarya, Mumbai: Central Chinmaya Mission Trust.

Tolle, Eckhart (2001). The power of Now. Mumbai: Yogi Impressions.

Walsch, Neale Donald (1995). Conversations with God (Book One). London: Hodder and Stoughton.

Zohar, Danah (2005).Spiritually intelligent leadership. Leader to Leader, 38 (Fall): 45-51. 


\section{APPENDIX 1: SHANKARACHARYA'S TATTVABODHA - STRUCTURE}

\section{INVOCATION}

\section{THE FOUR-FOLD QUALIFICATION}

a. Discrimination

b. Dispassion

c. The six-fold wealth:

i. Control of the mind

ii. Control of the sense organs

iii. Strict observance of one's duty

iv. Endurance of heat and cold, joy and sorrow, etc.

v. Faith in the words of the teacher and scriptures

vi. Single-pointedness of the mind

d. Intense desire for liberation

\section{ENQUIRY INTO THE TRUTH}

The firm conviction that "the Self is real, and all else is unreal."

Definitions of the Self - both indirect ("that which is not") and direct ("that which is"):

a. The three bodies:

i. The gross body

ii. The subtle body

iii. The causal body

b. The three states:

i. The waking state

ii. The dream state

iii. The deep sleep state

c. The five sheaths:

i. The food sheath

ii. The vital air sheath

iii. The mental sheath

iv. The intellectual sheath

v. The bliss sheath

d. The nature of the Self:
i. Existence
ii. Consciousness
iii. Bliss

\section{CREATION OF THE UNIVERSE}

a. The twenty-four elements

b. Maya

c. The evolution of the sattva aspect:

i. The organs of perception

ii. The inner controller

d. The evolution of the rajas aspect

e. The evolution of the tamas aspect

4. THE INDIVIDUAL SELF AND THE SUPREME SELF

An enquiry into the Great Statement: "That thou art"

\section{MAN OF REALIZATION}

A description of an enlightened soul

6. THE LAW OF ACTION

a. Agami karma

b. Sanchit karma

c. Prarbadh karma

d. Freedom from karma 


\title{
APPENDIX 2: SAMPLE OF COURSE MATERIAL
}

\author{
Ishavasya Upanishad
}

Shloka \#1:

ईशावास्यमिद् सर्व यत्किन्च जगत्यां जगत्।

तेन त्यक्तेन भुग्जीथा मा गृधः कस्य स्विद्धनम्।। १।।

isavasyam idam sarvam yat kincha jagatyam jagat

tena tyaktena bhunjithah ma grdhah kasya svid dhanam (1)

Synonyms:

Isa - by the Lord; avasyam - controlled; idam - this; sarvam - all; yat kincha - whatever; jagatyam within the universe; jagat - all that is animate or inanimate; tena - by Him; tyaktena - set-apart quota; bhunjithah - you should accept; ma - do not; grdhah - endeavour to gain; kasya svit - of anyone else; dhanam - wealth

Translation \#1:

Everything animate or inanimate that is within the universe is controlled and owned by the Lord.

One should therefore accept only those things necessary for himself, which are set aside as his quota, and one should not accept other things, knowing well to whom they belong.

Translation \#2:

Know that all this, whatever moves in this moving world, is enveloped by God.

Therefore find your enjoyment in renunciation; do not covet what belongs to others.

\section{APPENDIX 3: COURSE OUTLINE}

\section{LEADERSHIP SQ - THE VEDIC WAY}

Instructor: Prof. Tarun Pasricha

\section{Objective:}

Great leadership depends primarily on vision - not just any type of vision, but one that people can appreciate intellectually, emotionally, and spiritually. This course is based on the premise that ancient Indian wisdom as embodied in the Vedas can contribute directly to the nurturing of many of the above traits, resulting in leadership with a high SQ. Specifically, the course will source its learning from Vedanta - the essence of the Vedas - which have been a source of knowledge and spiritual transformation for millions across the world, since time immemorial. Besides contributing to leadership SQ, it is hoped that the course would encourage students to manage stress, enhance equanimity and lead to the realization that ultimately there is only one reality. This should be beneficial to character development and a useful source of strength and equipoise as they embark on their career in management.

\section{Detailed syllabus:}

The course will attempt to acquaint students with this ancient Indian philosophical tradition, based specifically on Shankaracharya's Tattvabodha and the Ishavasya Upanishad. It is expected that at the end of the course, students will not only be familiar with these particular treatises, but would have also imbibed several fundamental Vedantic concepts. Students would also be expected to put in considerable extra effort outside the classroom in the study of other spiritual treatises/concepts as directed by the course faculty. In particular, comparative presentations on selected western 'new age' spiritual literature will be an integral part of the course.

Following the oral tradition of the Vedas, the majority of the sessions would involve listening to a scholarly audio presentation (recorded) on the selected Vedantic treatise. The faculty will interrupt the recording 
periodically to provide clarifications of some of the more complex and unfamiliar issues, and encourage class discussion on these topics.

\section{Cases and exercises:}

1. Individual home assignment on Vedanta classes

2. Exercise and presentations on Book 1

3. Exercise and presentations on Book 2

\section{Session Plan:}

\begin{tabular}{|l|c|}
\hline Topic & No. of Sessions \\
\hline Shankaracharya's Tattvabodha & 6 \\
\hline Group presentations on Book 1 & 2 \\
\hline Ishavasya Upanishad & 4 \\
\hline Group presentations on Book 2 & 2 \\
\hline
\end{tabular}

\section{Evaluation Scheme:}

\begin{tabular}{|l|c|}
\hline Class Participation & 10 \\
\hline Individual Assignments & 20 \\
\hline Quizzes (2) & 20 \\
\hline Group Presentations & 20 \\
\hline End-of-term Exam & 30 \\
\hline Total & 100 \\
\hline
\end{tabular}

